茨城県南部のスギ花粉症

新井峻・中川 暁子

\title{
Japanese Cedar Pollinosis in the South of Ibaraki Prefecture
}

\author{
Takashi Arai and Akiko Nakagawa \\ (National Kasumigaura Hospital)
}

\begin{abstract}
A clinical study of 1206 patients with Japanese cedar pollinosis treated between January 1975 and December 1999 was performed and in addition, the amount of Japanese cedar and cypress pollen in the south of Ibaraki Prefecture was measured every spring from 1981 to 1999 (19 years).

The following findings were observed.

1) The age distribution of Japanese cedar pollinosis was highest in the 30-39-year-old group of females. In the younger age group (10 years or youger), pollinosis was more common in males than females.

2) The skin test positive rate for house dust (HD) was $46.3 \%$. The positive rate for pollens, orchard grass, short ragweed, lesser reedmace and Japanese hops, was 16.9, 20.2, 14.6 and 3.9\%, respectively.

3) The RAST positive rate for mites and HD was 46.3 and $21.3 \%$, respectively. The positive rate for pollens, orchard grass, short ragweed and mugwort, was 19.9, 14.8 and $9.5 \%$, respectively.

4) The mean pollen count of Japanese cedar and cypress over the 19 year period was 4298.5 / $\mathrm{cm}^{2}$. The highest pollen count was $16987 / \mathrm{cm}^{2}$ in 1995 .

5) A correlation was noted between the annual variations in the Japanese cedar and cypress pollen counts and the annual change in Japanese cedar pollinosis patient numbers. Since the peak in 1995, Japanese cedar pollinosis has tended to increase.
\end{abstract}

Key words : Japanese cedar pollinosis, the south of Ibaraki Prefecture, Japanese cedar and cypress pollen

\section{はじめに}

スギ花粉症に関する報告は, その基礎的研究から臨床 にわたり数多く行われて打り，またその発症には地域特 異性があることも多く報告1) 4) されている．1980年およ び1990年に当科に拈ける鼻アレルギ一症例について報 告5)6) したが，今回1975年より1999年までに当科アレル ギー外来を受診したスギ花粉症の臨床像, 検査成績につ いて検討し，若千の知見を得たので報告する。また， 1981年より継続的にスギ，ヒノキ科花粉飛散測定を行い, 各年ごとの飛散状況とスギ花粉症との関連性叔よび茨城 県内の他の地域に拈ける飛散状況との比較についても検
討したので報告する.

\section{対象および方法}

1975年 1 月から1999年12月まで当科アレルギー外来を 受診し，スギ花粉症(重複感作例を含む) と診断した1206 例を対象とした。

1) 診 断

症状発現時期, 鼻内所見, 鼻汁㧊よび血液好酸球検査, 副鼻腔 X 線検查, 皮膚テスト, 血清特異的 $\operatorname{IgE}$ 抗体検 查(以下RAST とする), 誘発テストにより行った。 皮膚テストは皮内テスト法を1975年より1983年まで全 
例に，1984年以降はRAST 陰性の場合アレルゲン確定 診断のためにスクラッチ法にて行った。診断エキスは鳥 居薬品製を用い，八ウスダスト(以下 $\mathrm{HD}$ とする)，ダ 二, スギ, ブタクサ, カナムグラ, ヒメガマ, カモガヤ, ヨモギ, アスペルギルス，ペニシリウム，カンジダを用 いた.

RAST は1982年より全例に行い，1991年まではぺー パーディスク法, 1992年以降はCAP法で行った. HD1, ダニ 1 ，スギ，ブタクサ，カモガヤ，ヨモギを用い，ス ギはスュア 1 以上，他の抗原はスコア 2 以上を陽性とし た.

スギ花粉症の診断基準として，スギ飛散シーズンに症 状を有し，皮膚テスト陽性またはRAST（スギ）スコア 1 以上とした.

\section{2 ）スギ，ヒノキ科花粉測定}

1981年より土浦市内の自宅敷地内にて周囲に遮蔽物の 比較的少ない地上約 $3 \mathrm{~m}$ の高さにダーラム型標準花粉 採集器を設置し，原則として毎年 1 月 1 日から 5 月上旬 のスギ，ヒノキ科花粉飛散終了時をで毎日測定した．測 定はスライドグラスの表面に白色ワセリンを薄く塗布し， 採集器のスライドホルダーに固定し, 午前 9 時に毎日交 換した。花粉の測定は, Carberla 液にて染色後 $1 \mathrm{~cm}^{2}$ のカバーグラスを 2 枚かけてスギ，ヒノキ科花粉数を数 え，それぞれの花粉数を平均し 1 日 $1 \mathrm{~cm}^{2}$ 当たりの花粉 数 $\left(\right.$ 個 $\left./ \mathrm{cm}^{2}\right)$ とした。

\section{結 果}

\section{1 ) 年齢・性別分布 (表 1$)$}

性別では全体では女性が多く，初診時年齢は男性では 10 歳代が最も多く, 次に 30 歳代であり, 女性は30歳代が 最も多く，次に20歳代であった. 10歳代以下の年齢層で は男性が多く，特に 9 歳以下の低年齢層で著明であった。 20歳代より50歳代では女性が多いことが特徽的であった。 初診時の最低年龄は， 2 歳 2 カ月の男児であった.

\section{2 ）皮膚反応陽性率 (スギを除く)（表 2 )}

HD は421例施行し，陽性率は $46.3 \%$ であった。ダニ は1983年まで219例に施行し，33.8\%であった．花粉は カモガヤ (415例) $16.9 \%$ ，ブタクサ(415例) $20.2 \%$ ，ヒメ ガマ(417例) $14.6 \%$ ，カナムグラ(415例) 3.9\%であった.

3 ) RAST 陽性率(スギを除く) (表 3 )

HD1 は1991年まで535例に施行し，21.3\%であった。 ダニ 1 は1991年以降738例に施行し，46.3\%であった.
表 1 年齢・珄別分布 $(1975 １ 999)$

\begin{tabular}{c|c|c}
\hline \hline 男 性 & 年 秢 & 女 $\quad$ 性 \\
\hline 58 例 & $0 \sim 9$ 歳 & 14 例 \\
138 & $10 \sim 19$ & 110 \\
101 & $20 \sim 29$ & 166 \\
118 & $30 \sim 39$ & 198 \\
66 & $40 \sim 49$ & 118 \\
28 & $50 \sim 59$ & 44 \\
20 & $60 \sim 69$ & 20 \\
4 & $70 \sim$ & 3 \\
\hline 533 & & 673
\end{tabular}

表 2 各抗原の皮膚反応陽性率 （皮内テスト）

\begin{tabular}{c|c|c}
\hline \hline 抗 原 & 陽性率(\%) & 施行例数 \\
\hline $\mathrm{HD}$ & 46.3 & 421 \\
\hline ダニ & 33.8 & 219 \\
\hline カモガヤ & 16.9 & 415 \\
\hline ブタクサ & 20.2 & 415 \\
\hline ヒメガマ & 14.6 & 417 \\
\hline カナムグラ & 3.9 & 415
\end{tabular}

表 3 各抗原の RAST 陽性率 (スコア 2 以上)

\begin{tabular}{c|c|c}
\hline \hline 抗 原 & 陽性率(\%) & 施行例数 \\
\hline $\mathrm{HD} 1$ & 21.3 & 535 \\
\hline ダニ1 & 46.3 & 738 \\
\hline カモガヤ & 19.9 & 1086 \\
\hline ブタクサ & 14.8 & 1082 \\
\hline ヨモギ & 9.5 & 1084
\end{tabular}

スギ以外の他の花粉は，カモガヤ(1086例) $19.9 \%$ ，ブタ クサ(1082例) $14.8 \% ， ヨ モ キ ゙(1084$ 例) $9.5 \%$ であった。

\section{4 ) 年別スギ，七ノキ科花粉総数 (図 1)}

各年のスギ，ヒノキ科花粉総数の推移をみると，1988 年以降増加の傾向が認められ，90年，93年，95年は大量 飛散年であった．特に1995年は15987個/ $\mathrm{cm}^{2}$ を記録した。 大量飛散の傾向は，82～88年，90～93年にかけては 3 年 周期の傾向があったが，以後隔年に变わり最近は一定の 


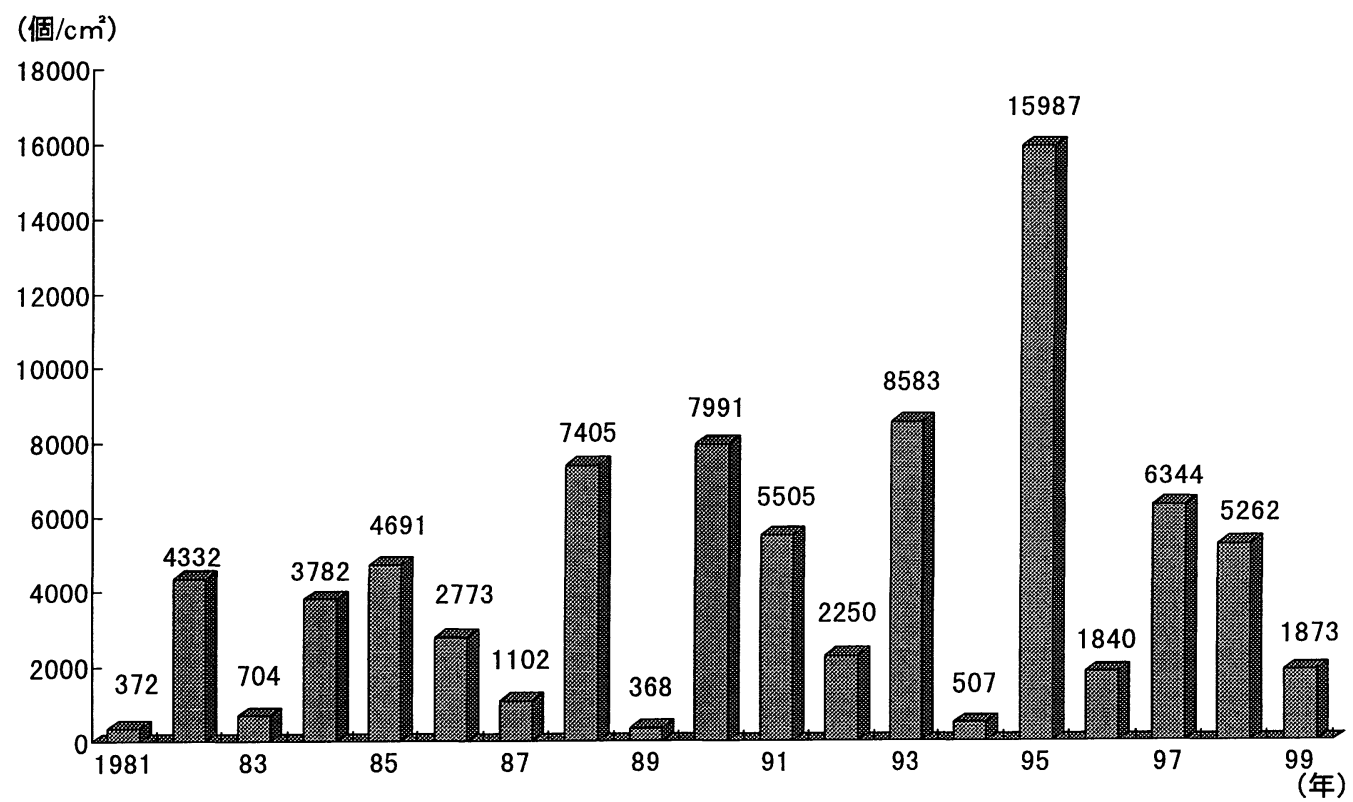

図 1 年別スギ, ヒノキ科花粉総数

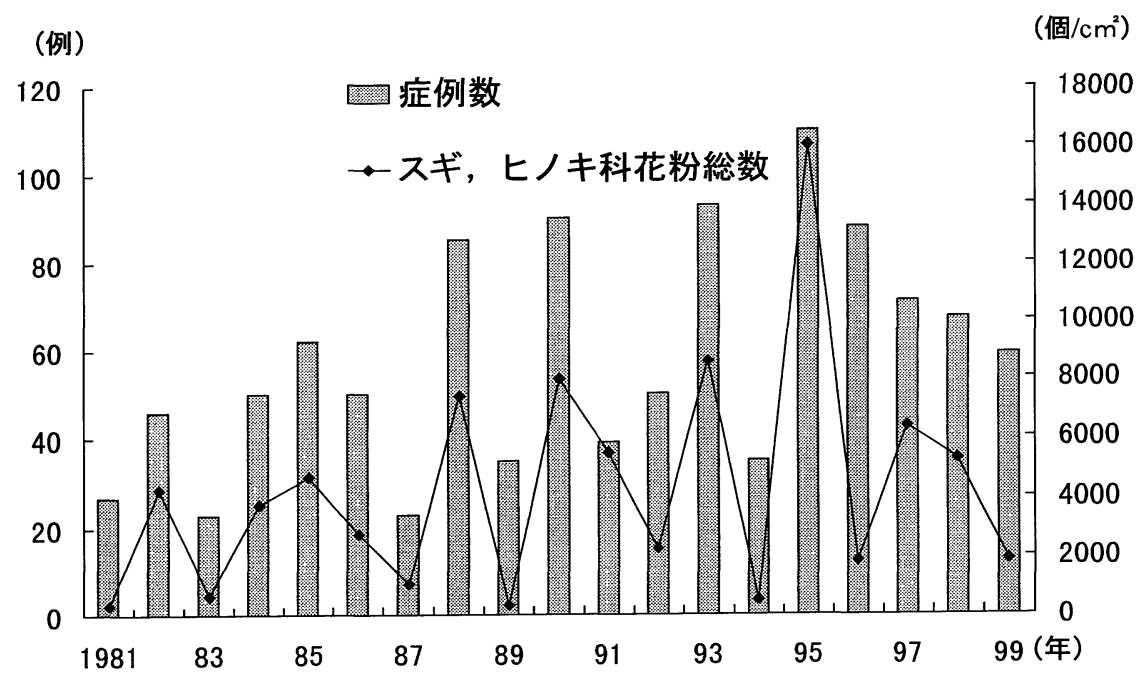

図 2 年別スギ, ヒノキ科花粉総数とスギ花粉症例数

パターンはみられない。19年間の平均值は 4298.5 個/ $\mathrm{cm}^{2}$ であった。

5 ) 年別スギ，ヒノキ科花粉総数とスギ花粉症(図 2 ) 花粉総数の年別の変化と初診スギ花粉症例の推移をみ ると，1988年，90年，93年，95年の大量飛散年で症例数 の増加がみられた. しかし，1996年は花粉数が減少した にもかかわらず症例数の増加が認められ, 以後花粉数の
増減と関係なく症例数の増加がみられた。

\section{考案}

スギ花粉症に関する統計は過去に多くの報告がみられ るが，性別でみると女性に多いことが示されてい る7) 10). これを年龄別にみると男性では10歳代にピー クがみられることが特徵とされている7). また，女性で 
は30歳代が最も多いことが示されており899)，われわれ の結果も同様であった。男性の 10 歳代に多いことは, 森 ${ }^{11)}$, 馬場ら ${ }^{7)}$ の疫学調査でも示されて和り, 森 ${ }^{11)}$ は 6 １7歳の度学調査に怙いて, ダ二抗体保有率とスギ抗体 保有率が男性ではほぼ同様に推移寸るのに対して, 女性 ではスギ抗体保有率は年齢とともに徐々に増加し, ダニ 抗体保有率は徐々に低下していることを報告し，若年の 男児に多い原因がダニによる感作が関係しているであろ らとしている。

われわれのスギ花粉症例をHDによる重複感作例に 限って検討してみると，19歳以下では男性が女性より多 く，20歳以上では女性が男性より多い結果がみられた。 スギ花粉症の発症には重複感作抗原としての HD, ダニ 抗原は10歳代以下の低年齢層に打いて男性の方により大 きな影響を持っていると考兄られた。

原因抗原の検査として皮膚テスト拈よびRASTを 行ったが，スギ以外の抗原ではいずれも HD，ダ二の陽 性率が高い值を示した，RAST では，HD 陽性率は皮 虐テスト（皮内テスト）に比べて低いことが指摘されい る12)。われわれの HD 検査成績に执いても，RAST 陽 性率 (21.3\%) 性度テスト陽性率 (46.3\%) に比べて低い 值であった。一方ダ二 1 陽性率 $(46.3 \%)$ は皮膚テスト (HD) の陽性率と同じ值を示した。これらのことからダ 二 1 陽性例はHDにも感作されていると考兄られた。 $\mathrm{HD}$ またはダニを同一抗原と考学ると，スギ花粉症の約 2 分の 1 が HD, ダニ抗原陽性であることは，その発症 に重要な要因となっていると思われた.

田中ら ${ }^{8)}$ のスギ花粉症の疫学調査によれば, スギ以外 の抗原に対する陽性率は $\mathrm{HD}$, ダニ, ブタクサ, カモガ ヤの順であることが示されている，スギ花粉症では $\mathrm{HD}$, ダニに感作されていることが多く，鼻粘膜過敏性 の元進を介してスギ抗体陽性者の発症を促進させる可能 性があることが指摘されている13)。

他の花粉類の陽性率に関しては, 花粉症全体の統計的 報告211415) では，カモガヤに代表されるイネ科の雑草， ブタクサ，ヨモギのキク科雑草の陽性率が高い．われわ れの統計でも, 皮膚テストではブタクサ, カモガヤ, ヒ メガマが16〜20\%の陽性率であり, RAST ではカモガ ヤ19.9\%，ブタクサ14.8\%の陽性率であり，他の花粉に よる重複感作が15～20\%あることが示された. ヒメガマ （皮膚テスト）は，当地の位置する霞ヶ浦を中心とした湖 沼に多く自生しているために検査を行ったが，カモガヤ
に代表されるイネ科雑草とほぼ同じ值の重複感作を認め た.

年別スギ，ヒノキ科花粉飛散総数の推移をみると 1988 年以降増加傾向が認められ, 特に超大量飛散年であった 1995年は15987個 $/ \mathrm{cm}^{2}$ を記録した. この年を中心として 1994年，95年，96年の茨城県内のスギ，七ノキ科花粉飛 散状況（表 4)をみると, 当地の飛散状況は他の地域とほ ぼ同様の傾向が認められた。また, 荻城県のスギ, ヒノ キ林占有率地域分布において高い值を示す県北部の測定 地点の大宮保健所は飛散総数も多い傾向がみられたが, スギ樹林の少ない当地を含む県南部地域(竜っ崎, 水海 道, 下館, 筑波等) 11995年は大量の飛散が認められた. 関東, 東海地域はスギ, 七ノキ科花粉飛散の多い地域と されている16)が, 茨城県全域のなかでスギ, ヒノキ科 樹林が比較的少ないとされる県南部に括いても年変動は あるが飛散量の多い地域と考兄られた。

年別スギ, ヒノキ科花粉総数とスギ花粉初発症例数と の関係をみると, 大量飛散年では症例数の増加が顕著で あった. 特に1995年は超大量飛散に伴い症例数の増加と ともに眼刺激症状, 咽喉頭刺激症状を訴兄る症例が多数 みられた ${ }^{17}$.

田中ら ${ }^{8)}$ はアンケートでの発症年齢から発症年数を換 算し, 年別発症人数の推移とスギ花粉総飛散数との関係 をみているが，発症者は1986年頃から増加しているもの の, その年の花粉数と発症者は必ずしも一致しないとし

表 4 茨城県に扣けるスギ, ヒノキ科花粉飛散状況 花粉総数 (個 $\left./ \mathrm{cm}^{2}\right)$

\begin{tabular}{l|c|c|c}
\hline \hline \multicolumn{1}{c|}{ 調査地点 } & 1994 年 & 1995年 & 1996年 \\
\hline 大宮保健所 & 645.2 & 24612 & 3040.8 \\
\hline 日立市 & 414.8 & 18342 & \\
\hline 湖来保健所 & 274.4 & 11133 & 1499.7 \\
\hline 竜ヶ崎保健所 & 394.1 & 12784 & 1647.2 \\
\hline 水海道保健所 & 488.6 & 27367 & 1402.7 \\
\hline 下館保健所 & 352.8 & 17554 & 1561.7 \\
\hline 筑波大学 & 322.5 & 14328 & 1905.8 \\
\hline 国立環境研 & 527.6 & 19706 & \\
\hline 土浦市* & 507 & 15987 & 1840
\end{tabular}

1994, ’95年：国立環境研 田村憲治氏より提供 1996年：筑波大 村上正孝氏より提供

* 土浦市永国の新井住宅地 
ている.われわれの症例でも，1996年は花粉数が減少し たにもかかわらず症例数の増加がみられ，以後花粉数の 増減に関係なく症例数の増加がみられたことは，1995年 の超大量飛散により感作された症例が多く，その後の増 加につながったとも考光られる。をた，最近のスギ花粉 症増加原因について，スギ，ヒノキ科花粉増加以外の要 因として大気污染の疫学調査 ${ }^{1819)}$ が行われて特り, 環 境因子の関与が推測されている.

\section{まとめ}

1975年より1999年までに受診したスギ花粉症1206例 （重複感作例を含む）について検討し，また1981年以降の 年別スギ，七ノキ科花粉飛散状況との関連性についても 検討した。

1. 性別では女性が多く, 初診時年齢別分布では男性 では10歳代が最も多く，女性では30歳代であった。

2. 皮膚反応陽性率(スギを除く)では HD が最も多 く, カモガヤ，ブタクサ，ヒメガマ，カナムグラの順で あった。

3. RAST 陽性率(スギを除く)ではダニ 1 が最も多 く, HD1，カモガヤ，ブタクサ，ヨモギの順であった.

4. 年別スギ, ヒノキ科花粉飛散総数の推移では, 1988年，90年，93年，95年に大量飛散がみられた．19年 間の平均值は4298.5個 $/ \mathrm{cm}^{2}$ であった.

1994年，95年，96年に観測された県内 8 力所に打ける 花粉飛散状況と比較し県南に位置する当地も飛散の多い 地域と考えられた。

5 . 年別花粉飛散状況と初診スギ花粉症例との関係で は，1988年，90年，93年，95年の大量飛散年に症例数の 増加が認められた. しかし1996年以降は花粉数の増減と 関係なく毎年増加傾向がみられた。

\section{参考文献}

1) 岸川禮子: スギ花粉症と地理疫学調査. 総合臨床 44 : $2140 \sim 2148,1995$

2 ) 宇佐神篤 : 花粉症 一最近の動向と地域特性について一. アレルギー診療 $14: 541 \sim 553,1988$.

3 ）宇佐神篤：花粉症の全国調查. JOHNS $10: 279 \sim 285$,
1994.

4 ) 斉藤洋三 : 関東地方の花粉症の地域特性. アレルギーの臨 床 $13: 164 \sim 168,1993$.

5 ) 新井 峻: 茨城県南部に扎ける鼻アレルギー一特にスギ 花粉症について一. 耳鼻 26 補 $1: 246 \sim 252,1980$.

6 ）新井 峻：土浦市に拁ける鼻アレルギーとスギ花粉飛散状 況. 日鼻誌 $29: 105,1990$.

7 ）馬場廣太郎, 森 朗子, 吉田博一 : スギ花粉症. 耳喉頭頸 $67: 230 \sim 239,1995$.

8 ) 田中 晃, 岩瀬朗子, 谷垣内由之: スギ花粉症の疫学 壬生町のアンケート調査から一。 日耳鼻 $102: 35 \sim 41$, 1999.

9 ）鵜飼幸太郎：三重県に括けるスギ花粉症疫学調査. CLINICIAN $42:$ :157 165, 1995.

10）坂口幸作, 坂口文雄, 牛島勝郎: アレルギー検查から見た スギ花粉症患者の特長. 耳鼻臨床 $79: 1081 \sim 1087,1986$.

11）森 朗子：小児に打けるスギ花粉症の感作と発症に関与す る因子について.アレルギー $44: 7 \sim 15,1995$.

12）中島香代子：ハウスダスト・ダニ鼻アレルギーに护ける皮 虐テストの検討.アレルギー $39: 410 〜 417,1990$.

13）山越隆行, 今野昭義, 藤田洋祐, 他: スギ花粉症の自然史. アレルギーの臨床 $17: 203 \sim 208,1997$.

14）斉藤洋三 : 関東地方のスギ花粉症の地域特性. アレルギー の臨床 $13: 164 \sim 168,1993$.

15）堀口茂俊, 久松健一, 霜村真一, 他 : アレルギー外来の現 況一統計学的考察 1一. 耳鼻臨床 補79：118 124, 1995.

16）長野 準, 西間三馨, 岸川僼子, 他：日本列島の空中花粉 II (長野 準編). 33 36頁, 北隆館, 東京, 1992.

17）新井 峻: 本年度のスギ, ヒノキ科花粉飛散状況と症状の 特徵. 日鼻誌 $34: 276,1995$.

18）榎本雅夫, 硲田猛真, 獄 良博, 他: 和歌山県に扣けるス ギ花粉特異的 IgE 抗体陽性率の疫学調査 -1995年の調査 と1985年，1990年の比較一. 日耳鼻 $102: 1311 \sim 1317$, 1999.

19) 竹中 洋 : スギ花粉症 一疫学一. 気道アレルギー’95(冨 岡㺵夫, 今野昭義, 足立 満, 他編). $14 \sim 29$ 頁, メディ カルレビュー社, 東京, 1995.

$\left(\begin{array}{l}\text { 原稿受付 : 平成 } 12 \text { 年 } 6 \text { 月 } 1 \text { 日 } \\ \text { 原稿採択 : 平成 } 12 \text { 年 } 7 \text { 月 } 19 \text { 日 } \\ \text { 別刷請求先 : 新井 峻 } \\ \text { 干 } 300-8585 \text { 土浦市下高津2-7-14 } \\ \text { 国立霞ヶ浦病院耳鼻咽喉科 }\end{array}\right)$

